DOI https://doi.org/10.30525/978-9934-26-173-2-20

\title{
ЗАСОБИ СПОРТИВНО-ПАТРІОТИЧНОГО ВИХОВАННЯ
}

\author{
Пелипась Д. С. \\ викладач кафедри теорії та методики фізичного виховання \\ ДЗ «Луганський національний університет імені Тараса Шевченка» \\ м. Старобільськ, Украӥна
}

В останнє десятиріччя зростає важливість патріотичного виховання молоді, становлення іiі самосвідомості та відданості держави. Нажаль через недалекоглядність української влади за часи незалежності молодь піддавалася згубному впливу через ЗМІ. Український патріотизм у деяких частинах суспільства почав вважитися непопулярним та негативним явищем. Лише суспільно-політичні потрясіння виправили ситуацію, а патріотичне виховання стало проникати у всі заклади освіти та навчальні дисципліни. Фізична культура не є винятком. Як зазначає О. Отравенко, професійна підготовка майбутніх фахівців має бути наскрізне пронизана патріотичним духом. Організація науково-педагогічної, навчально-пізнавальної діяльності, особливо, якщо це стосується формування національної свідомості, у закладах вищої освіти потребує постійного вдосконалення, пошуку нових форм та методів впливу на самосвідомість студентів [1, с. 276]. Тому, наша робота спрямована на ознайомлення із засобами спортивно-патріотичного виховання, які доречно використовувати на уроках фізичної культури та в позаурочній діяльності.

У процесі урочних занять фізичною культурою ми пропонуємо використовувати:

1. Варіативний модуль «Хортинг». Представлений модуль грунтується на елементах самооборони, які взяті із національного бойового мистецтва «Хортинг». Модуль підвищує обізнаність молоді щодо культури та історії України. Надає уміння та навички самооборони, підвищує рівень загальної фізичної підготовленості.

2. Варіативний модуль «Військово-спортивні ігри». Модуль формує позитивне відношення до професії військового, надає інформацію щодо історії розвитку ігор на теренах України. Сприяє розвитку фізичних якостей, логіки та мислення здобувачів загальної середньої освіти.

3. Застосування елементів народних танців та українських народних ігор у початковій ланці. Безумовно, формування патріотичної свідомості 
слід формувати змалечку. Тому, ознайомлення 3 ігрової та хореографічною спадщиною України доречно робити в початковій ланці.

У позаурочній діяльності ми пропонуємо такі заходи та свята:

1. Проведення Олімпійського тижня та Олімпійського уроку. Знання олімпійської спадщини незалежної України сприяють зацікавленості учнями спортом, здобутками своїх земляків. Філософія олімпізму формує гуманізм, толерантність та демократизм, що не дає розвитку ксенофобії, нацизму та інших шкідливих ідеологій.

2. Організація гри «Джура». Представлена гра має комплексний вплив на свідомість учня. По-перше, ознайомлює з історією України. По друге сприяє розвитку рухових якостей та укріпленню здоров'я. По третє формує уміння та навички долікарської допомоги та виживання на природі. Гра «Джура» загалом має на меті формування всебічно розвинутого патріота України.

3. Свято «Козацький гарт». Проведення цього свята має бути приурочено Захисникам та Захисницям України, розвивати повагу до військовим та вдячність за їхньої самовідданість. Захід має проходити в атмосфері козацької культури 3 використанням естафет, вправ на спритність, силу, швидкість тощо. Здобувачі загальної середньої освіти мають відчувати в процесі свята зв'язок із великою історичною спадщиною та розуміти, що вони мають бути гідними нащадками свої предків.

Наступні наші кроки щодо спортивно-патріотичного виховання будуть направленні на дослідження впливу представлених засобів на патріотичні цінності здобувачів загальної середньої освіти.

\section{Література:}

1. Отравенко О. В. Національно-патріотична спрямованість професійної підготовки майбутніх учителів фізичної культури. Вісник Луганського національного університету імені Тараса Шевченка. № 6(303), Жовтень. 2016. Ч.1 С. 272-281. 